\title{
MLLT6 wt Allele
}

National Cancer Institute

\section{Source}

National Cancer Institute. MLLT6 wt Allele. NCI Thesaurus. Code C53080.

Human MLLT 6 wild-type allele is located in the vicinity of $17 q 21$ and is approximately 22 $\mathrm{kb}$ in length. This allele, which encodes protein AF-17, is involved in the modulation of transcription by RNA polymerase II. Acute nonlymphocytic leukemia is associated with the translocation $\mathrm{t}(11 ; 17)(\mathrm{q} 23 ; \mathrm{q} 21)$ of the gene and the MLL gene. 